\title{
Polymorphism of the VEGF gene and its association with growth traits in four goat breeds
}

\author{
Q.J. Jin ${ }^{1}$, X.T. Fang ${ }^{1}$, C.L. Zhang ${ }^{1}$, L. Yang ${ }^{1}$, J.J. Sun ${ }^{1}$, D.X. Chen ${ }^{1}$, X.Y. Shi ${ }^{1}$, Y. Du ${ }^{1}$, \\ X.Y. Lan $^{2}$ and H. Chen ${ }^{1 \#}$ \\ ${ }^{1}$ Institute of Cellular and Molecular Biology, Xuzhou Normal University, Xuzhou, Jiangsu 221116, China \\ ${ }^{2}$ College of Animal Science and Technology, Northwest A\&F University, \\ Shaanxi Key Laboratory of Molecular Biology for Agriculture, Yangling, Shaanxi 712100, China
}

\begin{abstract}
The vascular endothelial growth factor (VEGF) is a regulator of angiogenesis which is an important physiological adaptation to increased metabolic demand. Thus, mutations of this gene may exert a significant influence on animal growth. We screened the exons of the caprine VEGF gene using PCR-SSCP and DNA sequencing methods in 459 individuals from four goat breeds to identify sequence variations that may have an effect on protein structure and function, and might be related to different phenotypes of growth traits. Two single nucleotide polymorphisms (SNPs) (GU014696:g.49 $G>C$ and GU014696:g.270G>A) were identified in the P3 locus of the caprine VEGF gene. Significant associations were observed between the genotypes of the P3 locus and body length, body height and chest circumference. Individuals with genotype P3-B had a significantly longer body length and higher body height than individuals containing genotype P3-AB. Thus, animals of genotype $\mathrm{P} 3-\mathrm{AB}$ should be culled in a selection programme for fast growth. It is suggested that P3-B could be used as a molecular marker in marker-assisted selection (MAS).
\end{abstract}

Keywords: VEGF gene, caprine, single nucleotide polymorphism (SNP), genetic variation, PCR-SSCP

${ }^{\#}$ Corresponding author. E-mail: chenhong1212@263.net

\section{Introduction}

Domestic animals have been subjected to a long history of breeding desirable phenotypic traits slowly into their populations. Classical Mendelian genetics were used to select desirable traits. However, these breeding programmes do not allow for optimal control over specific phenotypic characteristics. As a consequence many breeders now-a-days focussed mainly on DNA markers for animal selection and breeding through marker assisted selection (MAS). This field is strongly focusing on gene loci and polymorphisms that have been discovered to be specifically associated with desirable traits related to eating quality of meat and growth efficiency. The focus in this study is on the caprine VEGF gene as the most plausible candidate gene affecting economically important traits in livestock.

The vascular endothelial growth factor is also called VEGF-A, following the identification of several $V E G F$-related factors (VEGF-B, VEGF-C, VEGF-D, VEGF-E). The human VEGF gene is located on chromosome 6p21.3 (Vincenti et al., 1996) and consists of eight exons exhibiting alternate splicing to form a family of proteins (Tischer et al., 1991). The splice forms of VEGF differ in biological properties such as the receptor types that they recognize and their interaction with heparan sulfate proteoglycans (Houck et al., 1991; Tischer et al., 1991). The vascular endothelial growth factor is a highly specific mitogen for vascular endothelial cells (Gerber et al., 1998). It significantly influences vascular permeability and also plays a role in neovascularisation (Mukhopadhyay et al., 1998). A potent synergism between VEGF and bFGF in the induction of angiogenesis has been observed (Cross \& Claesson-Welsh, 2001). Angiogenesis is an important physiological adaptation to increased metabolic demand. Vascular endothelial growth factor is important for bone formation and is essential for normal growth plate morphogenesis, which includes blood vessel invasion and cartilage remodelling (Gerber et al., 1999; Zelzer et al., 2002). The VEGF has also been implicated in bone repair (Street et al., 2002). During bone repair, VEGF is required not only for blood vessel formation, but also for normal callus volume and mineralization (Peng et al., 2002; Colnot et al., 2003). The VEGF is a major inducer of angiogenesis during embryogenesis and has been implicated in neuronal survival, neuroprotection, regeneration, growth, differentiation and migration (Sun et al., 2003; Ferrara, 2004; Greenberg \& Jin, 2004). Several studies have shown that polymorphisms within the VEGF 
gene could influence the etiology of a variety of pathological conditions such as diabetic retinopathy (Awata et al., 2002), prostate cancer (Lin et al., 2003) and breast cancer (Krippl et al., 2003). Thus, variations in this gene may exert vast influences on animal growth. However, to date, no studies on the effects of the polymorphisms of the VEGF gene on the economically important traits in livestock have been published. We therefore screened the entire exons of the caprine VEGF gene to identify sequence variations that might have an effect on protein structure and function and might be related to different phenotypes of growth traits.

\section{Material and Methods}

Genomic DNA samples were obtained from 459 unrelated goats belonging to four breeds: the Boer goat $(\mathrm{BE}, \mathrm{n}=111)$, Chinese Xuhuai white goat $(\mathrm{XH}, \mathrm{n}=108)$, Chinese Haimen goat $(\mathrm{HM}, \mathrm{n}=136)$ and a crossbred population $(\mathrm{BE} \times \mathrm{XH}, \mathrm{n}=104)$. They were reared in the Jiangsu Province of China. DNA samples were extracted from leucocytes according to Mullenbach et al. (1989). Four growth traits (body height, body length, cannon circumference and chest circumference) were measured when the goats were 18 months old (Luo \& Wang, 1998). Body length index (\%, body length/body height $\times 100)$, chest circumference index (\%, chest circumference/body height $\times 100)$, cannon circumference index $(\%$, cannon circumference/body height $\times 100)$ and trunk index $(\%$, chest circumference/body length $\times 100)$ were calculated as described by Luo \& Wang (1998). Data including eight growth traits for the four breeds were summarized by descriptive statistics and are presented in Table 1.

As there was no available sequence information of the caprine VEGF gene, comparative alignments of amino-acid sequences and nucleotide sequences from cattle and sheep were used to design PCR primers that would amplify complete exons and some introns of the caprine VEGF gene (Table 2).

For all assays processed in this study, the same conditions were used: $50 \mathrm{ng}$ genomic DNA, $0.5 \mu \mathrm{M}$ of each primer, $1 \times$ buffer (including $1.5 \mathrm{mM} \mathrm{MgCl}_{2}$ ), $200 \mu \mathrm{M}$ dNTPs and 0.625 units of Taq DNA polymerase (MBI). The cycling protocol was $5 \mathrm{~min}$ at $94{ }^{\circ} \mathrm{C}, 35$ cycles at $94{ }^{\circ} \mathrm{C}$ for $30 \mathrm{~s}$, annealing for $35 \mathrm{~s}$ at $72{ }^{\circ} \mathrm{C}$, with a final extension at $72{ }^{\circ} \mathrm{C}$ for $10 \mathrm{~min}$.

The SSCP method was used to scan mutations within the amplified regions (Zhang et al., 2007). Aliquots of $5 \mu \mathrm{L}$ PCR products were mixed with a $5 \mu \mathrm{L}$ denaturing solution ( $95 \%$ formamide deionized, 25 mM EDTA, $0.025 \%$ xylene-cyanole and $0.025 \%$ bromophenol blue), heated for $10 \mathrm{~min}$ at $98{ }^{\circ} \mathrm{C}$ and chilled immediately in ice. Denatured DNA was subjected to $10 \%$ polyacrylamide gel electrophoresis (PAGE) in $1 \times$ TBE buffer and a constant voltage $(150 \mathrm{~V})$ for $15 \mathrm{~h}$ at a constant temperature of $4{ }^{\circ} \mathrm{C}$. The gel was stained with silver nitrate and visualized with a $2 \% \mathrm{NaOH}$ solution (containing $0.1 \%$ formaldehyde) (Zhang et al., 2007). The PCR products which represent different PCR-SSCP genotypes, including both homozygous and heterozygous genotypes, were purified with the GenElute PCR DNA Purification Kit (Sigma-Aldrich Corporation, USA) and sequenced using the ABI 377 sequencer according to the manufacture's instructions (Applied Biosystems, USA). Sequences were aligned using web based CLUSTAL-W (http://www.ebi.ac.uk/clustalw/index.html) software.

Population genetic indices (e.g. observed and expected heterozygosity and effective allele numbers) were calculated by the Nei methods (Nei \& Li, 1979). The polymorphism information (PIC) content was calculated using the Botstein's methods (Botstein et al., 1980). The software SPSS (Version 17.0) was used to analyze the relationship between genotypes and growth traits in the goats. The adjusted linear model is $\mathrm{Y}_{\mathrm{ijklmn}}=\mu+\mathrm{B}_{\mathrm{i}}+\mathrm{S}_{\mathrm{j}}+\mathrm{D}_{\mathrm{jk}}+\mathrm{A}_{1}+\mathrm{G}_{\mathrm{m}}+(\mathrm{SG})_{\mathrm{jm}}+\mathrm{e}_{\mathrm{jklmn}}$, where $\mathrm{Y}_{\mathrm{ijklmn}}$ is the trait measured on each animal, $\mu-$ the overall population mean, $B_{i}$ - the fixed effect associated with the $i^{\text {th }}$ breed, $S_{j}$ - the fixed effect associated with the $j^{\text {th }}$ sire, $D_{j k}$ - the fixed effect associated with $k^{\text {th }}$ dam with sire $j, A_{1}$ - fixed effect due to the $1^{\text {th }}$ age, $G_{m}$ - the fixed effect associated with $\mathrm{m}^{\text {th }}$ genotype, $(\mathrm{SG})_{\mathrm{jm}}$ - interaction between the $\mathrm{j}^{\text {th }}$ sire and the $\mathrm{m}^{\text {th }}$ genotype and $e_{i j k l m n}$ - the random error. The least square means estimates (LSM) with standard errors and multiple range tests for different genotypes and growth traits were used.

\section{Results}

According to the strong similarity between cattle, sheep and goats, six pairs of primers were designed to detect polymorphisms in exons and some introns of the caprine VEGF gene. The primers amplified the desired sized fragments from different regions of the caprine VEGF gene.

SSCP polymorphisms were detected in the P3 locus of the caprine VEGF gene. The number of bands 
and their positions in the gel clearly showed the occurrence of DNA sequence variations (Figure 1). The PCR products of the different SSCP variants were sequenced and the partial sequence of the caprine VEGF gene was deposited in GenBank with accession number GU014696. The exon-intron boundaries of the caprine $V E G F$ gene were predicted by aligning the goat and cattle DNA sequences with the known structure of the bovine VEGF gene.

Table 1 Descriptive statistics of the recorded growth traits for four goat breeds

\begin{tabular}{|c|c|c|c|c|c|}
\hline Breeds (n) & Traits & Mean & s.e. & Min & Max \\
\hline \multirow[t]{8}{*}{$\mathrm{BE}(111)$} & $\mathrm{BH}(\mathrm{cm})$ & 65.55 & 0.69 & 45.00 & 98.00 \\
\hline & $\mathrm{BL}(\mathrm{cm})$ & 77.00 & 0.75 & 52.00 & 99.00 \\
\hline & $\mathrm{CaC}(\mathrm{cm})$ & 10.30 & 0.12 & 6.50 & 14.00 \\
\hline & $\mathrm{ChC}(\mathrm{cm})$ & 82.61 & 1.03 & 50.00 & 99.00 \\
\hline & BLI (\%) & 118.57 & 1.52 & 84.69 & 177.55 \\
\hline & ChCI (\%) & 126.96 & 1.78 & 80.95 & 182.22 \\
\hline & $\mathrm{CaCI}(\%)$ & 15.83 & 0.21 & 10.87 & 22.92 \\
\hline & TI (\%) & 108.43 & 1.70 & 57.95 & 167.31 \\
\hline \multirow[t]{8}{*}{ XH (108) } & $\mathrm{BH}(\mathrm{cm})$ & 61.36 & 0.51 & 49.00 & 73.00 \\
\hline & $\mathrm{BL}(\mathrm{cm})$ & 70.63 & 0.74 & 53.00 & 84.00 \\
\hline & $\mathrm{CaC}(\mathrm{cm})$ & 8.22 & 0.06 & 7.00 & 9.50 \\
\hline & $\mathrm{ChC}(\mathrm{cm})$ & 77.09 & 0.80 & 59.00 & 93.00 \\
\hline & BLI (\%) & 115.06 & 0.71 & 133.33 & 115.06 \\
\hline & ChCI (\%) & 125.79 & 1.01 & 101.61 & 150.88 \\
\hline & $\mathrm{CaCI}(\%)$ & 13.47 & 0.12 & 11.29 & 16.67 \\
\hline & TI (\%) & 109.48 & 0.83 & 92.65 & 145.28 \\
\hline \multirow[t]{8}{*}{ HM (136) } & $\mathrm{BH}(\mathrm{cm})$ & 56.80 & 0.31 & 50.00 & 67.00 \\
\hline & $\mathrm{BL}(\mathrm{cm})$ & 65.43 & 0.49 & 54.00 & 84.00 \\
\hline & $\mathrm{CaC}(\mathrm{cm})$ & 8.47 & 0.08 & 6.00 & 11.00 \\
\hline & $\mathrm{ChC}(\mathrm{cm})$ & 75.35 & 0.39 & 65.00 & 85.00 \\
\hline & BLI (\%) & 115.21 & 0.62 & 93.44 & 130.77 \\
\hline & ChCI (\%) & 132.94 & 0.75 & 115.25 & 152.94 \\
\hline & $\mathrm{CaCI}(\%)$ & 14.91 & 0.12 & 10.91 & 17.24 \\
\hline & TI (\%) & 115.64 & 0.68 & 96.34 & 140.00 \\
\hline \multirow[t]{8}{*}{$\mathrm{BE} \times \mathrm{XH}(104)$} & $\mathrm{BH}(\mathrm{cm})$ & 65.12 & 0.41 & 54.00 & 74.00 \\
\hline & $\mathrm{BL}(\mathrm{cm})$ & 73.73 & 0.69 & 60.00 & 88.00 \\
\hline & $\mathrm{CaC}(\mathrm{cm})$ & 8.63 & 0.08 & 7.50 & 11.00 \\
\hline & $\mathrm{ChC}(\mathrm{cm})$ & 79.23 & 0.79 & 62.00 & 100.00 \\
\hline & BLI (\%) & 113.23 & 0.80 & 94.37 & 133.33 \\
\hline & $\mathrm{ChCI}(\%)$ & 121.67 & 0.94 & 94.29 & 143.75 \\
\hline & $\mathrm{CaCI}(\%)$ & 13.26 & 0.10 & 11.43 & 16.92 \\
\hline & TI (\%) & 107.62 & 0.69 & 92.86 & 125.00 \\
\hline
\end{tabular}

$\mathrm{BE}=$ Boer goat; $\mathrm{XH}=$ Xuhuai goat; $\mathrm{HM}=$ Haimen goat; $\mathrm{BE} \times \mathrm{XH}=$ Boer goat $\times$ Xuhuai goat;

$\mathrm{BH}=$ body height; $\mathrm{BL}=$ body length; $\mathrm{CaC}=$ cannon circumference; $\mathrm{ChC}=$ chest circumference; $\mathrm{BLI}=$ body length index; $\mathrm{ChCI}=$ chest circumference index; $\mathrm{CaCI}=$ cannon circumference index; $\mathrm{TI}=$ trunk index. $\mathrm{n}=$ number of observations; s.e. $=$ standard error. 
Table 2 The primer pair sequences and their information on the VEGF gene in goats

\begin{tabular}{|c|c|c|c|}
\hline Loci & Sequence & $\begin{array}{l}\text { Annealing } \\
\text { temperature }\end{array}$ & Size (bp) \\
\hline $\mathrm{P} 1$ & $\begin{array}{l}\text { F:5'- ACTTCTGGGCTGTTCTCGTTCC -3' } \\
\text { R:5'- AGAGGTTGAGATGGCTGGATGG -3' }\end{array}$ & $61.0^{\circ} \mathrm{C}$ & 350 \\
\hline $\mathrm{P} 2$ & $\begin{array}{c}\text { F:5'- CTGCCGCTGCCCATTCTT -3' } \\
\text { R:5'- CCAACAGACCTTCCCACTCATC -3' }\end{array}$ & $59.5^{\circ} \mathrm{C}$ & 184 \\
\hline P3 & $\begin{array}{l}\text { F:5'- CCTTTCCCGTGGTGGTTAC -3' } \\
\text { R:5'- CACCTGCATGGTGATGTTGA -3' }\end{array}$ & $58.0^{\circ} \mathrm{C}$ & 320 \\
\hline P4 & $\begin{array}{l}\text { F:5'- TCACCATCTGAACGCCTCT -3' } \\
\text { R:5'- CTCCATCCCACTGCTGCTA -3' }\end{array}$ & $59.0^{\circ} \mathrm{C}$ & 245 \\
\hline P5 & $\begin{array}{l}\text { F: 5'- TCTTGTCTTCCGCTGTGGCAT -3' } \\
\text { R: 5'- CTCTGACTTGCTCGCCCTCTG -3' }\end{array}$ & $65.0^{\circ} \mathrm{C}$ & 327 \\
\hline P6 & $\begin{array}{l}\text { F:5'- TGGAGGCTAGGACTGTGCTTT -3' } \\
\text { R:5'- GCGGCTATGGGTAGTTCTGTG -3' }\end{array}$ & $60.0^{\circ} \mathrm{C}$ & 241 \\
\hline
\end{tabular}

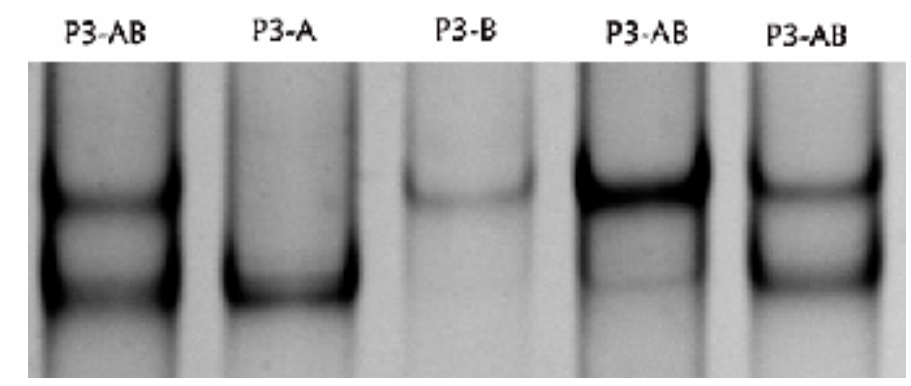

Figure 1 Genotypes at $\mathrm{P} 3$ locus in the caprine VEGF gene.

Table 3 Genotype and haplotype frequencies for the sequence variations observed in the study

\begin{tabular}{|c|c|c|c|c|c|c|}
\hline \multirow{2}{*}{ Breed } & \multicolumn{3}{|c|}{ Observed genotype (P3 locus) } & \multirow{2}{*}{ Total } & \multicolumn{2}{|c|}{ Haplotypes frequencies } \\
\hline & $\begin{array}{c}\text { P3-A } \\
\text { (CC-AA) } \\
\end{array}$ & $\begin{array}{c}\text { P3-AB } \\
(\mathrm{CG}-\mathrm{AG})\end{array}$ & $\begin{array}{c}\text { P3-B } \\
\text { (GG-GG) }\end{array}$ & & $\mathrm{C}-\mathrm{A}$ & G-G \\
\hline $\mathrm{BE}$ & 3 & 16 & 92 & 111 & 0.099 & 0.901 \\
\hline $\mathrm{XH}$ & 6 & 19 & 83 & 108 & 0.144 & 0.856 \\
\hline HM & 10 & 25 & 101 & 136 & 0.165 & 0.835 \\
\hline $\mathrm{BE} \times \mathrm{XH}$ & 5 & 13 & 86 & 104 & 0.111 & 0.889 \\
\hline
\end{tabular}

BE - Boer goat; XH - Chinese Xuhuai white goat; HM - Chinese Haimen goat; $\mathrm{BE} \times \mathrm{XH}$ - crosses.

The comparisons among these sequences revealed two mutations. In detail: GU014696:g.270G>A caused a predicted amino acid change from Glu to Lys. The other one, GU014696:g.49 G>C, was located in the intron of the caprine VEGF gene. Three genotypes identified in the SSCP analyses for the P3 locus showed homozygous P3-A and P3-B, and heterozygous P3-AB by haplotypes C-A and G-G, respectively. 
Based on SSCP and responsive sequence variations, the genotype and allelic frequencies were analyzed (Table 3). Differences in genotypic and allelic frequencies at the P3 locus among the four goat breeds were analyzed using a $\chi 2$-test, which was performed by SPSS software (version 17.0) (Table 4). There was no significant distribution difference of genotype and allele $(\mathrm{P}<0.05)$. With PopGen software (version 3.2) and according to the Botstein's methods (Botstein et al. 1980), the population genetic indices (i.e. gene homozygosity, gene heterozygosity, effective allele numbers $(\mathrm{Ne})$ and polymorphism information content (PIC)) were calculated (Table 5).

Table 4 P value differences for genotypic and allelic frequencies between breeds at P3 locus

\begin{tabular}{lcccc}
\hline Breeds & BE & HM & XH & BE $\times$ XH \\
\hline BE & & 0.432 & 0.159 & 0.675 \\
HM & 0.363 & & 0.831 & 0.550 \\
XH & 0.112 & 0.518 & & 0.296 \\
BE $\times$ XH & 0.872 & 0.462 & 0.163 &
\end{tabular}

$\mathrm{P}$ values in the upper triangle of the table represent differences in genotypic frequencies between two breeds; In the lower triangle of the table, $\mathrm{P}$ values represent differences in allelic frequencies between two breeds. BE - Boer goat; XH - Chinese Xuhuai white goat; HM - Chinese Haimen goat; BE×XH - crosses.

Table 5 PIC, He, Ho and Ne at two polymorphic loci of caprine VEGF gene

\begin{tabular}{clcccc}
\hline Locus & Breeds & $\begin{array}{c}\text { Gene } \\
\text { homozygosity } \\
(\text { Ho) }\end{array}$ & $\begin{array}{c}\text { Gene } \\
\text { heterozygosity } \\
(\mathrm{He})\end{array}$ & $\begin{array}{c}\text { Effective } \\
\text { allele } \\
\text { numbers } \\
(\mathrm{Ne})\end{array}$ & $\begin{array}{c}\text { Polymorphism } \\
\text { information } \\
\text { content } \\
\text { (PIC) }\end{array}$ \\
\hline & BE & 0.8559 & 0.1441 & 1.217 & 0.162 \\
$\mathrm{P3}$ & $\mathrm{XH}$ & 0.8241 & 0.1759 & 1.326 & 0.216 \\
& $\mathrm{HM}$ & 0.8162 & 0.1838 & 1.382 & 0.238 \\
& $\mathrm{BE} \times \mathrm{XH}$ & 0.8750 & 0.1250 & 1.245 & 0.178 \\
\hline
\end{tabular}

BE - Boer goat; XH - Chinese Xuhuai white goat; HM - Chinese Haimen goat; BE×XH - crosses.

Boer goats produced the highest means for body height, body length, cannon circumference and chest circumference, while Haimen goats produced the lowest mean values for the four growth traits (Table 1).

To investigate the effects of the P3 locus, the relationships between genotypes for the effects on variation in body height, body length, cannon circumference, chest circumference and body length index in 459 goats (Table 6) were analysed. The results indicated a significant effect of P3 locus on body length, body height and chest circumference. Individuals with genotype P3-AB were associated with a decreased body length and body height compared with genotype P3-B.

\section{Discussion}

Body height, body length, chest circumference and cannon circumference are four main growth traits which have important impacts on the production of goat meat and pelt. Therefore, breeding for optimal growth traits and higher gains is a major consideration in goat breeding programmes. Most genetic variation is represented by single nucleotide polymorphisms and many of them are believed to cause phenotypic differences between individuals. Identification of causative mutations that affect growth traits will greatly enhance the progress towards this goal. 
Table 6 Association analysis of the P3 locus with growth traits in goat breeds (Boer goat, Xuhuai white goat, Haimen goat, and Boer goat $\times$ Xuhuai goat)

\begin{tabular}{lrrrr}
\hline $\begin{array}{c}\text { Growth trait } \\
(\mathrm{n}=459)\end{array}$ & \multicolumn{4}{c}{ P3 Locus(means \pm standard error of means) } \\
\cline { 2 - 5 } $\mathrm{BH}(\mathrm{cm})$ & $59.88^{\mathrm{ab}} \pm 0.99$ & $59.76^{\mathrm{a}} \pm 0.73$ & $62.43^{\mathrm{b}} \pm 0.33$ & 0.001 \\
$\mathrm{BL}(\mathrm{cm})$ & $69.96^{\mathrm{ab}} \pm 1.82$ & $69.19^{\mathrm{a}} \pm 1.04$ & $71.85^{\mathrm{b}} \pm 0.43$ & 0.031 \\
$\mathrm{CaC}(\mathrm{cm})$ & $8.67 \pm 0.23$ & $8.64 \pm 0.15$ & $8.95 \pm 0.07$ & 0.105 \\
$\mathrm{ChC}(\mathrm{cm})$ & $75.54 \pm 1.83$ & $76.84 \pm 1.00$ & $78.90 \pm 0.45$ & 0.041 \\
$\mathrm{BLI}(\%)$ & $116.76 \pm 2.19$ & $115.92 \pm 1.21$ & $115.38 \pm 0.55$ & 0.773 \\
$\mathrm{ChCI}(\%)$ & $126.26 \pm 2.45$ & $129.24 \pm 1.66$ & $126.92 \pm 0.68$ & 0.359 \\
$\mathrm{CaCI}(\%)$ & $14.52 \pm 0.38$ & $14.50 \pm 0.21$ & $14.40 \pm 0.10$ & 0.881 \\
$\mathrm{TI}(\%)$ & $109.02 \pm 2.69$ & $111.99 \pm 1.53$ & $110.46 \pm 0.59$ & 0.466
\end{tabular}

\footnotetext{
Within columns means with different superscript, $a$ and $b$, are significantly different $(\mathrm{P}<0.05)$; $\mathrm{BH}=$ body height; $\mathrm{BL}=$ body length; $\mathrm{CaC}=$ cannon circumference; $\mathrm{ChC}=$ chest circumference; $\mathrm{BLI}=$ body length index; $\mathrm{ChCI}=$ chest circumference index; $\mathrm{CaCI}=$ cannon circumference index; $\mathrm{TI}=$ trunk index. $\mathrm{n}=$ number of observations.
}

The VEGF gene was investigated because of the important role of VEGF in angiogenesis which is an important physiological adaptation to increased metabolic demand. Several studies have shown that polymorphisms within the VEGF gene could influence the etiology of a variety of pathological conditions (Awata et al., 2002; Krippl et al., 2003; Lin et al., 2003). Because of its biological function, the VEGF gene represents an excellent candidate gene that may influence growth traits in goats.

The exons of the caprine VEGF gene were amplified and screened for polymorphisms. In a sample consisting of 459 goats, two DNA sequence polymorphisms based on SSCP were identified, and sequencing GU014696:g.270G $>$ A demonstrated a predicted amino acid change from Glu to Lys, and GU014696:g.49 $\mathrm{G}>\mathrm{C}$, was located in an intron of the caprine VEGF gene. Comparisons of genetic diversity of the four goat breeds demonstrated that BExXH had the highest homozygosity and BE the lowest PIC in two loci. Gene heterozygosity and the PIC of the indigenous breeds ( $\mathrm{HM}$ and $\mathrm{XH})$ were higher than in the foreign breed (BE).

The association between the different genotypes and growth traits in the 459 goats was assessed. In an associated study, indications were found that support a trait relationship of the two SNPs in the P3 locus with body length, body height and chest circumference of goats. Individuals with Genotype P3-B displayed a significantly $(\mathrm{P}<0.05)$ higher body length and body height compared to Genotype $\mathrm{P} 3-\mathrm{AB}$ individuals. Furthermore, there was a tendency $(\mathrm{P}>0.05)$ that $\mathrm{P} 3-\mathrm{B}$ genotype individuals had a higher cannon circumference and chest circumference than those possessing genotype $\mathrm{P} 3-\mathrm{AB}$, although no statistical differences are presented. GU014696:g.270G>A caused a predicted amino acid change from Glu to Lys. Thus, it might cause a functional difference to the caprine VEGF gene that caused phenotypic differences between individuals. Moreover, the two SNPs could be in linkage disequilibrium with another SNP in the caprine VEGF gene with greater effects on the traits. Introns have also been revealed to affect transcriptional efficiency of numerous genes in a variety organism.

It must be mentioned that the sample size within each genotype was not very large. If a larger number of goats was analysed, differences would probably have been clearer. However, these results provide useful information on genes that should be studied. 


\section{Acknowledgements}

This work was supported by Natural Science Foundation of Jiangsu Province (No.BK2008120), the National "863" Programme of the P.R. China (No. 2008AA10Z138), the "13115" Sci-Tech Innovation Programme of Shaanxi Province (2008ZDKG-11), Research Fund for the Doctor Programme of Higher Education of China (No.20080712001), Natural science fund for colleges and universities in Jiangsu Province (09KJD180002), Natural Science Foundation of Xuzhou Normal University (No.07XLA08; No.KY2007019), and the Young Topnotch Researcher Support Project of Northwest A\&F University ( No.QNGG-2009-007).

\section{References}

Awata, T., Inoue, K., Kurihara, S., Ohkubo, T., Watanabe, M., Inukai, K., Inoue, I. \& Katayama, S., 2002. A common polymorphism in the 5'-untranslated region of the VEGF gene is associated with diabetic retinopathy in type 2 diabetes. Diabetes 51, 1635-1539.

Botstein, D., White, R.L., Skolnick, M. \& Davis, R.W., 1980. Construction of a genetic linkage map in man using restriction fragment length polymorphisms. Am. J. Hum. Genet. 32, 314-331.

Colnot, C., Thompson, Z., Miclau, T., Werb, Z. \& Helms, J.A., 2003. Altered fracture repair in the absence of MMP9. Development 130, 4123-4133.

Cross, M.J. \& Claesson-Welsh, L., 2001. FGF and VEGF function in angiogenesis: Signalling pathways, biological responses and therapeutic inhibition. Trends Pharmacol. Sci. 22, 201-207.

Ferrara, N., 2004. Vascular endothelial growth factor: Basic science and clinical progress. Endocr. Rev. 25, 581-611.

Gerber, H.P., McMurtrey, A., Kowalski, J., Yan, M., Keyt, B.A., Dixit, V. \& Ferrara, N., 1998. Vascular Endothelial Growth Factor Regulates Endothelial Cell Survival through the Phosphatidylinositol 3'Kinase/Akt Signal Transduction Pathway: REQUIREMENT FOR Flk-1/KDR ACTIVATION. J. Biol. Chem. 273, 30336-30343.

Gerber, H.P., Vu, T.H., Ryan, A.M., Kowalski, J., Werb, Z. \& Ferrara, N., 1999. VEGF couples hypertrophic cartilage remodeling, ossification and angiogenesis during endochondral bone formation. Nat. Med. 5, 623-628.

Greenberg, D.A. \& Jin, K., 2004. VEGF and ALS: the luckiest growth factor? Trends Mol. Med. 10, 1-3.

Houck, K.A., Ferrara, N., Winer, J., Cachianes, G., Li, B. \& Leung, D.W., 1991. The vascular endothelial growth factor family: identification of a fourth molecular species and characterization of alternative splicing of RNA. Mol. Endocrinol. 5, 1806-1814.

Krippl, P., Langsenlehner, U., Renner, W., Yazdani-Biuki, B., Wolf, G., Wascher, T.C., Paulweber, B., Haas, J. \& Samonigg, H., 2003. A common $936 \mathrm{C} / \mathrm{T}$ gene polymorphism of vascular endothelial growth factor is associated with decreased breast cancer risk. Int. J. Cancer 106, 54-55.

Lin, C.C., Wu, H.C., Tsai, F.J., Chen, H.Y. \& Chen, W.C., 2003. Vascular endothelial growth factor gene-460 $\mathrm{C} / \mathrm{T}$ polymorphism is a biomarker for prostate cancer. Urology 62, 374-377.

Luo, J., Wang, Z.Y., 1998. Practical production technology of meat goat. The Publishing House of Shaanxi Science and Technology, Xi' an, China.

Mullenbach, R., Lagoda, P.J. \& Welter, C., 1989. An efficient salt-chloroform extraction of DNA from blood and tissues. Trends Genet. 5, 391.

Mukhopadhyay, D., Nagy, J.A., Manseau, E.J. \& Dvorak, H.F., 1998. Vascular permeability factor/vascular endothelial growth factor-mediated signaling in mouse mesentery vascular endothelium. Cancer Res. $58,1278-1284$.

Nei, M. \& Li, W.H., 1979. Mathematic model for studying genetic variation in terms of restriction endonucleaes. Proc. Natl. Acad. Sci. USA. 76, 5269-5273.

Peng, H., Wright, V., Usas, A., Gearhart, B., Shen, H.C., Cummins, J. \& Huard, J., 2002. Synergistic enhancement of bone formation and healing by stem cell-expressed VEGF and bone morphogenetic protein-4. J. Clin. Invest. 110, 751-759.

Street, J., Bao, M., Deguzman, L., Bunting, S., Peale, F.V., Ferrara, N., Steinmetz, H., Hoeffel, J., Cleland, J.L. \& Daugherty, A., 2002. Vascular endothelial growth factor stimulates bone repair by promoting angiogenesis and bone turnover. P. Natl. Acad. Sci. Usa. 99, 9656-9661. 
Sun, Y., Jin, K., Xie, L., Childs, J., Mao, X.O., Logvinova, A. \& Greenberg, D.A., 2003. VEGF-induced neuroprotection, neurogenesis, and angiogenesis after focal cerebral ischemia. J. Clin. Invest. 111, 1843-1851.

Tischer, E., Mitchell, R., Hartman, T., Silva, M., Gospodarowicz, D., Fiddes, J.C. \& Abraham, J.A., 1991. The human gene for vascular endothelial growth factor. Multiple protein forms are encoded through alternative exon splicing. J. Biol. Chem. 266, 11947-11954.

Vincenti, V., Cassano, C., Rocchi, M. \& Persico, M.G , 1996. Assignment of the vascular endothelial growth factor gene to human chromosome 6p21. 3. Circulation 93, 1493-1495.

Zelzer, E., McLean, W., Ng, Y.S., Fukai, N., Reginato, A.M., Lovejoy, S., D'Amore, P.A. \& Olsen, B.R., 2002. Skeletal defects in VEGF120/120 mice reveal multiple roles for VEGF in skeletogenesis. Development 129, 1893-1904.

Zhang, C.L., Wang, Y., Chen, H., Lan, X.Y. \& Lei, C.Z., 2007. Enhance the efficiency of single-strand conformation polymorphism analysis by short polyacrylamide gel and modified silver staining. Anal. Biochem. 365, 286-287. 